\title{
Authentic Leadership and Organizational Commitment: The Mediating Role of Positive Psychological Capital
}

\author{
Paulo Rego, Miguel Pereira Lopes, José Luís Nascimento \\ School of Social and Political Sciences - University of Lisbon (Portugal) \\ pjrrego@gmail.com,mplopes@iscsp.ulisboa.pt,.jnascimento@iscsp.ulisboa.pt
}

Received: June 2015

Accepted: December 2015

\section{Abstract:}

Purpose: This study analyzes the mediating role of positive psychological capital in the relationship between authentic leadership and organizational commitment.

Design/methodology/approach: This quantitative study presents a model in which were considered as variables mediating the relationship between authentic leadership and organizational commitment, the four dimensions of positive psychological capital (optimism, resilience, self-efficacy, hope).

Findings: The results showed that positive psychological capital mediates the relationship between authentic leadership and organizational commitment. However, they also indicate that this mediation is only made for three of the four dimensions of positive psychological capital (self-efficacy, hope and optimism). They also show that resilience negatively affects organizational commitment.

Originality/value: The value of this study is to strengthen the interest in the study of positive psychological capital as a mediating variable and the importance of development that each of its dimensions and the impact they may have on other variables, as demonstrated by the results.

Keywords: authentic leadership, organizational commitment, positive psychological capital 


\section{Introduction}

Individuals' commitment to their organizations has been considered a critical issue in management studies. This is so because organizational commitment can change due to several factors (Meyer, Allen \& Topolnytsky, 1998a). Some studies point to the influence of leadership on organizational commitment (Harter, Schmidt \& Hayes, 2002). It is therefore natural that organizations turn to leadership and the leader's role as a way of finding the desired organizational context of optimism (Luthans \& Avolio, 2003). That's why one of the strategies followed by some organizations includes testing and implementing new types of leadership. This is the case of authentic leadership that positively influences individuals' commitment to the organization, as some authors have found (Walumbwa, Avolio, Gardner, Wernsing \& Peterson, 2008).

Other authors have studied the relationship between authentic leadership and positive psychological capital, and suggest in their studies that, among other things, authentic leadership promotes positive psychological capital and positive emotions (Rego, Sousa, Marques \& Cunha, 2012). Authentic leaders meet the needs of organizations and individuals who look to their leaders as role models of character, integrity, and authenticity. They give them a direction and help them give a meaning to their work and their lives (Gardner, Avolio, Luthans, May \& Walumbwa, 2005). Authentic leadership is characterized by being transparent, principled and truthful with others, acting in accordance with their values, beliefs and opinions, and maintaining an authentic and genuine relationship (Gardner et al., 2005; Ilies, Morgeson \& Nahrgang, 2005; Walumbwa et al., 2008; Kernis, 2003). This means that the higher the level of perceived authenticity, the more committed individuals are to achieving goals objectives (Kernis, 2003; Kernis \& Goldman, 2005).

Authentic leadership, which is based on the behavioural pattern of the leader and his relationship with the followers, promotes a positive ethical climate and fosters employees' positive psychological capacities (Walumbwa et al., 2008), which can be quite useful for organizations. Not only does it positively affect individuals' behaviours and attitudes and prompt them to develop their organizational citizenship behaviours, but also achieves desirable behaviour and performance (Ilies et al., 2005; Rego et al., 2012). That said the starting question for this research is:

To what extent is positive psychological capital a mediator of the relationship between determination of authentic leadership and organizational commitment?

This article proceeds in the following way in order to answer this question. First we review the literature on organizational commitment, authentic leadership and positive psychological capital. Then we formulate the hypotheses for the theoretical model proposed (Figure 1) by analyzing the relationship between authentic leadership and organizational commitment. Finally, we present the method, results and discussion of the findings. We then draw 
conclusions and highlight the main limitations of the study and make suggestions for future research.

\section{Theory and Hypotheses}

\subsection{Organizational Commitment}

Becker (1960) conducted early studies of organizational commitment emerged in the 1960s. He stated that commitment was a construct that explained the various types of behaviours considered by individuals to be an investment in organizations that ultimately constrain all their action and future. Other authors have addressed this issue, developing a construct, but not a consensual definition accepted by everyone, in the words of Nascimento, Lopes and Salgueiro (2008).

Meyer and Herscovitch (2001) reported that, when analyzing all settings, there was something common to all of them and it helped to define the construct as a psychological link between individual and organization, and that was a force that stabilized and directed their behaviour. According to Nascimento et al. (2008), the Meyer and Allen multidimensional model (Meyer \& Allen, 1991), which is composed of three organizational commitment components (affective, normative, and continuance) enjoys greater consensus, acceptance and use.

Meyer and Allen (1997) define affective behaviour as the way workers are tied to the organization in emotional terms. It can come from their own perception of just how they are treated and respected by the organization and the confidence they have in their superiors. These authors uphold that an employee who feels fulfilled and satisfied at work will want to stay with the organization. Continuance commitment is how employees feel connected to the organization, as it takes account of the costs of their departure and the fact that if they decide to leave, they may lose their entire investment. On the other hand, if employees see no way of changing jobs, their level of commitment increases (Meyer \& Allen, 1997). Finally, we have normative commitment, which is associated with the moral component of obligation and duty. According to Meyer and Allen (1997), employees feels a duty of responsibility to the organization, which leads them to act competently but without enthusiasm or commitment.

More recently, based on work already done, some authors have referred to the existence of organisational commitment profiles. This was the case of Meyer and Parfyonova (2010), who referred to two commitment profiles associated with the relationship between the normative and affective components, and another, where the normative component was associated with calculative component. These authors do not mention how each of the Meyer and Allen (1991) 
components relate independently, but rather how form and intensity as these same components relate to each other.

\subsection{Authentic Leadership}

The concept of authentic leadership was developed on the basis of the attitudes and behaviours of leaders who positively influence their followers and the models that incorporated positive organizational behaviour (POB). This emerged in the early $21^{\text {st }}$ century as an area of interest, in which additional studies have been conducted in the areas of transformational and ethical leadership (Avolio, Gardner, Walumbwa, Luthans, \& May, 2004; Gardner et al., 2005; Harter, 2002; Ilies et al., 2005).

Luthans and Avolio (2003) define the construct of authentic leadership as "a process designed to build on the positive psychological capacities and a highly developed organizational context, which results in greater self-awareness and a positive self-regulated behavior by leaders and colleagues, fostering a positive self-development" (Luthans \& Avolio, 2003: page 243).

Ilies et al. (2005) presented a model of authentic leadership with four dimensions (self-consciousness, unbiased processing, authentic behaviour, and authentic relational orientation). In turn, Gardner et al. (2005) attempted to integrate the various perspectives and definitions of the construct and put forward a model of authentic leadership and development of followers, focusing on components of self-awareness and self-regulation of authentic leadership. These authors identified several factors associated with authentic self-regulation, such as internal regulation, balanced information processing, relational transparency, and authentic behaviour. They also say that even stating that authenticity is associated with high levels of cognitive, emotional and moral development.

According to Walumbwa et al. (2008), the models presented by Ilies et al. (2005) and Gardner et al. (2005) were strongly influenced by the concept of authenticity (Kernis, 2003). Based on these studies Walumbwa et al. (2008) redefined the concept of authentic leadership presented by Luthans and Avolio (2003) with a new definition as "a pattern of leader behavior that promotes both positive psychological capacities and a positive ethical climate, to foster self-awareness, internalized moral perspective, balanced processing of information, and relational transparency in the work of leaders with subordinates, fostering positive self-development" (Walumbwa et al., 2008: page 94).

According to Walumbwa et al. (2008) each of these dimensions has characteristics that help describe the behaviour of the leader and allow them to be recognized as authentic. Accordingly, associated with the self-awareness dimension, is the knowledge that leaders have of their strengths and weaknesses and the impact that they have on others. The second 
dimension, internalized moral perspective, refers to self-regulating behaviour based on values and principles and not because of external pressure. The balanced information processing scale is characterized by the leader's ability to set goals, carefully examining the relevant information before making a decision. Finally the relational dimension focuses on the leader's transparency and ability to generate a climate of trust between everyone, while allowing the sharing of thoughts and emotions.

Walumbwa et al. (2008) reported that this construct was initially considered as having five distinct but related components. These are self-awareness, relational transparency, domestic regulation (i.e. authentic behaviour), balanced information processing and positive moral perspective. He upholds that the internal regulation and positive moral perspective dimensions have been transformed into a single dimension called internal moral perspective, which involves the internal drive of a leader to achieve integrity of behaviour, i.e. consistency between values and actions. This is because these two dimensions have become consistent with internal standards and the values themselves and are therefore conceptually equivalent.

In view of the empirical evidence, Walumbwa et al. (2008), and the concept of authentic leadership of Kernis (2003) and Kernis and Goldman (2005), can be treated as a higher order of global construct, represented by four dimensions. Walumbwa et al. (2008) found that variance attributed to true global leadership was more important than the variance attributed to each of its dimensions.

\subsection{Positive Psychological Capital}

Positive Psychology research emerged about 15 years ago. Instead of traditional psychology, which focused on the negative aspects of human health, they focused their study on what is good in people, making them more productive (Luthans, Luthans \& Luthans, 2004).

Studies in this area later stimulated the appearance of two different streams of research that supported positivity and management based on the strengths of the organization. This resulted in positive organizational scholarship (POS) and positive organizational behaviour (POB) which originate from positive psychology (Seligman, 2005).

The literature reports that POS argues that more stable behaviour and consequent psychological characteristics result, as part of the character and positive virtues, and in turn, $\mathrm{POB}$ argues that behavioural characteristics must be seen primarily as a result of positive psychological states. In other words, POS and POB represent distinct ethical assumptions, since they point to different components of reality as a key element in explaining the positive behaviors (Lopes, 2013). 
To Luthans, Youssef and Avolio (2007), POB focuses on the individual level and examines various forces and positive psychological capacities that can be measured and evaluated. Development focuses on a perspective of positive results in performance, which results in improved organizational performance (Luthans, Avolio, Walumbwa \& Li, 2005; Luthans \& Youssef, 2004).

Positive psychological capital (PsyCap) is defined as "a positive psychological state of development that is characterized by having the confidence to take on and put the necessary effort to succeed at challenging tasks (self-effectiveness); make a positive attribution about succeeding now and in the future (optimism); be persevering towards goals and when you need to redirect the paths to success (hope) and, when shaken by problems with adversity, sustain and recover, go further and beyond to achieve success (resilience)." (Luthans, Youssef et al., 2007: page 3).

These authors refer to these four (interacting) psychological skills that best harmonize with the criteria of $\mathrm{POB}$, and this gives rise to the name of the construct, positive psychological capital (PsyCap).

\subsection{Authentic Leadership as a Predictor of Organizational Commitment}

In the three components forming part of Meyer and Allen's (1991) model, organizational commitment, is predictive of the behaviour of workers in the organization to which they belong, indicating how they position themselves and are connected to it. This has an influence on performance and absenteeism (Meyer, Standley, Herscovitch \& Topolnytsky, 2002; Ng \& Feldman, 2008; Mathieu \& Zajac, 1990).

Meyer et al. (2002), report that each dimension of the Meyer and Allen organizational commitment model (Meyer \& Allen, 1991) has a history that explains individuals' connection to the organization.

Affective commitment is associated with personal characteristics (Mathieu \& Zajac, 1990), such as perceived competence, age (as workers grow older, they have fewer job opportunities and increase their investments), educational attainment (there is a negative relationship with this dimension since it is related to the possibility of more alternative employment). However, some authors, point to professional features as predecessors of this dimension, such as seniority in the organization, which is related to organizational dependence (Meyer, Irving \& Allen, 1998b; Mathieu \& Zajac, 1990), job satisfaction and professional experience associated with a greater sense of responsibility that therefore leads to greater commitment (Meyer et al., 1998b). Personal characteristics, the alternative of changing employment and seniority are part of the history of calculative commitment (Allen \& Meyer, 1990). Finally, Allen and Meyer (1990) state 
that the background of normative commitment is related to socialization experiences from the employee's relationship with the organization.

Given these studies and those of Harter et al. (2002), Walumbwa et al. (2008) states that authentic leadership is directly related to increased organizational commitment (in particular the affective dimension) due to the behavioural pattern of the authentic leader, because it can positively affect the behaviours and attitudes of employees, developing commitment, organizational citizenship behaviours and performance (Ilies et al., 2005; Rego et al., 2012.). This causes followers to feel more committed to achieving the goals and objectives that have been set, given their degree of perceived authenticity (Kernis, 2003; Kernis \& Goldman, 2005). We have therefore formulated the following hypothesis:

H1: Authentic leadership positively influences individuals' commitment to the organization.

\subsection{Authentic Leadership As a Predictor of Psychological Capital}

Some studies point to the fact that the authentic leader demonstrates confidence, optimism, hope and resilience, able to influence his followers and thus their development through emotional spread and positive social relationships stimulating so all PsyCap of his followers (Gardner et al., 2005; Avolio et al., 2004; Ilies et al., 2005; Norman, Luthans \& Luthans, 2005). It is in this sense that Gardner et al. (2005) argues that authentic leaders "leave positive psychological states accompanying the optimum levels of self-esteem and psychological well-being, such as confidence, optimism, hope and resilience, to model and promote the development of these states in others" (Gardner et al., 2005: page 345). Other studies, argue that the way individuals perceive the psychological state of the authentic leader has influence on the development of their positive psychological capacities (PsyCap), this is about hope and resilience, optimism and self-effectiveness (Norman et al., 2005; Avolio et al., 2004; Ilies et al., 2005), consistently with the possibility of these capabilities being developed.

As previously mentioned, authentic leadership, through the behavioral patterns of its leaders, influences and encourages the development of positive psychological capacities in their followers, by contagion or transmission, thus leading to higher levels of self-effectiveness, hope, optimism and resiliency (Avolio et al., 2004; Yammarino, Dionne, Schriesheim \& Dansereau, 2008; Ilies et al., 2005; Norman et al., 2005).

Through emotions, criticism and constructive feedback and their ability to remain hopeful and confident, authentic leaders are able to influence optimism, self-effectiveness and hope in their followers (Avolio et al., 2004; Luthans, Youssef et al., 2007; Ilies et al., 2005). Norman et al. 
(2005) suggest that perception of positive psychological states in the authentic leader by these followers has a positive influence on followers' resilience. In view of this, we have put forward the following hypotheses:

H2: Authentic leadership positively influences the PsyCap of followers.

H2a: Authentic leadership positively influences self-effectiveness.

H2b: Authentic leadership positively influences hope.

H2c Authentic leadership positively influences resilience.

H2d: Authentic leadership positively influences optimism.

\subsection{Positive Psychological Capital As a Predictor of Organizational Commitment}

Luthans, Youssef et al. (2007) report in their study that each of the four features of positive psychological capital (PsyCap) can be developed and have a significant impact on employees' attitudes, behaviour and performance and that the effect of development of PsyCap on attitudes is greater among employees who have a higher tendency to develop it as they have a behavioural pattern compatible with organizational goals and objectives.

There are other authors who corroborate this, suggesting that the employees most likely to develop PsyCap are those who, in view of the expectation that they will be more successful due to their greater optimism and belief in their abilities, end up feeling more satisfied with their work and committed to the organization (Luthans, Youssef et al., 2007; Luthans, Avey, ClappSmith \& Li, 2008).

Avey, Reichard, Luthans and Mhatre (2011) assessed the impact of positive psychological capital on attitudes, behaviour and performance of employees. They divide employees into two categories: those who by their actions, and taking account of the organization's goals and targets, are considered undesirable and/or desirable by Human Resources or Management itself. They conclude, among other things, that all dimensions of PsyCap (self-effectiveness, optimism, hope and resilience) have an influence on employee attitudes considered desirable, i.e. that there is a positive relationship between PsyCap and job satisfaction, organizational commitment and psychological wellbeing.

Youssef and Luthans (2007) refer to the fact that positive psychological dimensions such as hope, optimism and resilience are positively related to organizational commitment, while Avey et al. (2011) suggest that all dimensions of positive psychological capital are positively correlated with organizational commitment. Regarding this, we have developed the following hypotheses: 
H3: PsyCap positively influences employees' organizational commitment.

H3a: Self-effectiveness positively influences organizational commitment.

H3b: Hope positively influences organizational commitment.

H3C: Resilience positively influences organizational commitment.

H3D: Optimism positively influences organizational commitment.

\subsection{Mediation Hypotheses}

As already mentioned, authentic leadership influences organizational commitment and positive psychological capital. This is due to the leader's behavioural pattern. It can be assumed that authentic leadership directly and/or indirectly influences organizational commitment with positive psychological capital. Based on the theories and results of the various authors, we can assert the following hypotheses on mediation:

H4: PsyCap mediates the relationship between authentic leadership and organizational commitment.

H4a: Self-efficacy mediates the relationship between authentic leadership and organizational commitment.

H4b: Hope is a mediator of the relationship between authentic leadership and organizational commitment.

H4C: Resilience is a mediator of the relationship between authentic leadership and organizational commitment.

H4d: Optimism is a mediator of the relationship between authentic leadership and organizational commitment.

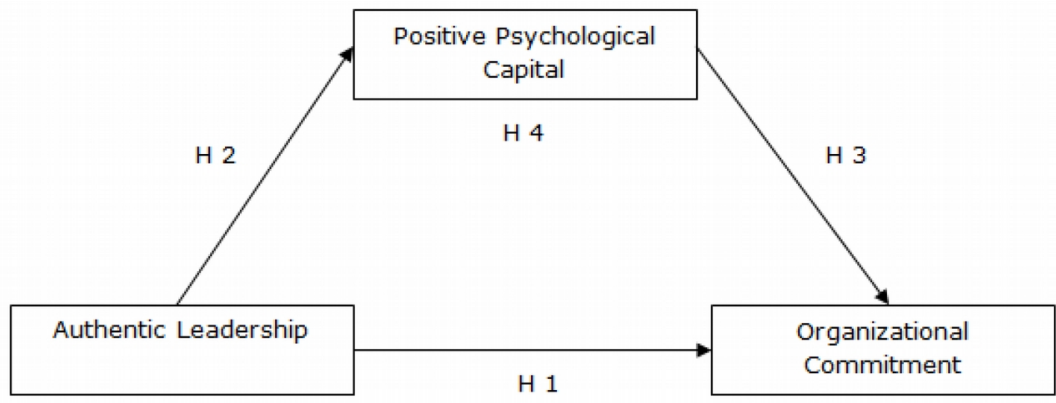

Figure 1. Research Model and Hypotheses 


\section{Methodology}

\subsection{Data Collection and Sample}

Data was collected in an anonymous questionnaire that included questions about the three variables referenced in this study. The respondents were working students at a large Portuguese state university. The data were collected from November 2013 to March 2014.

The study consisted of convenience sampling and the data came from 309 employees working in the public or private sector. 59.9\% of the respondents were female, aged between 18 and 65 , with a mean age of 34.79 years. $24.3 \%$ of the respondents had been working for less than a year in their current organization and $23 \%$ held managerial positions.

\subsection{Measurement of Organizational Commitment}

The latest Meyer and Allen version was used (1997), adapted and validated for Portugal by Nascimento et al. (2008). The questionnaire consisted of 19 items representing the three components (affective, normative and continuance). The answers to the questionnaire used a Likert scale ranging from 1 , "strongly disagree", to 7, "strongly agree".

Using LISREL (version 8.8) we conducted a confirmatory analysis of the model with all items comprising the three scales. We also tested the author's model (M1) and a first one-dimensional solution (M2), obtaining values above the reference figures. This meant that, after successive confirmatory analyses, we reached a final one-dimensional solution (M3) consisting of the items CO06_a, CO09_a, CO11_a, CO15_a, CO10_n and CO18_n.

The results obtained by the M1 model show that the values of the adjustment measures of goodness of fit are not within the parameters deemed acceptable by Hair, Black, Babin, and Anderson (2010). We then went on to a first one-dimensional solution (M2), obtaining values above the reference value. Given the results, we performed a confirmatory analysis of the one-dimensional model (M3) consisting of items CO06_a, CO09_a, CO11_a, CO15_a, CO10_n and CO18_n. The values obtained (X2: 10.35; RMSEA: 0.022; GFI: 0.98; X2 / df: 1,15; Model AIC: 34.35$)$ for the latter factor solution, showing a significant improvement in the indicators of goodness of fit.

Given the results, we chose this model (M3), which suggests the existence of a profile of commitment, going against the theoretical framework of Meyer and Allen (1991). In this particular case, there is evidence of a strong relationship between the affective and normative component, as suggested by Meyer and Parfyonova (2010). 
This M3 model solution fits the dominant profile of impairment AC / NC - which according to these authors, reports the most committed, positive, motivated and healthiest employees, bringing this advantage to the organization.

\subsection{Measurement of Authentic Leadership}

We used the Authentic Leadership Questionnaire - 16 (Copyright (C) 2007 Authentic Leadership Questionnaire, ALQ -16) developed by Avolio, Gardner and Walumbwa. All rights reserved in all media. Distributed by Mind Garden, Inc. www.mindgarden.com) properly translated into Portuguese and reviewed by bilingual professionals. The questionnaire consisted of 16 items representing the four dimensions of the construct (self-awareness, relational transparency, internalized moral perspective, and balanced processing), and included a Likert scale, ranging from 0 "never" to 4 "frequently if not always". Examples of items included in the questionnaire are: Tells the hard truths; their actions are consistent with their beliefs; Understands how their actions impact on others.

Using LISREL (version 8.8), we tested the model (M1), proposed by the author, the one-dimensional model (M2) and a second order factor solution (M3). All items comprising four scales were used in the first confirmatory factor analysis. The results determined that there was no need to extract any items because its loading factor was greater than 0.5 , i.e., according to the criteria defined by Hair et al. (2010).

We found, however, that the correlation between the four dimensions was excessively high, ranging between 0.82 and 0.93 . These results suggest a one-dimensional model, which confirmed our decision to test the one-dimensional model (M2) and the second-order factor analysis model (M3) to determine the weight of each variable in the construction of a fourdimensions integrative variable that corresponds to authentic leadership. Several authors have raised the issue of latent variables strongly correlated within a loose fit of the final model, particularly due to phenomena of multicollinearity (Hair et al., 2010).

However, when we compared goodness of fit measurements in both models, we found that M1 was the one that had the best indicators (X2: 248.89; RMSEA: 0.71; GFI: 0.84; X2 / df: 2,57; Model AIC: 324.89), meeting the criteria set by Hair et al. (2010). We therefore decided to use it. 


\subsection{Measurement of Positive Psychological Capital}

To measure positive psychological capital, we used the PsyCap Questionnaire - 12 (PCQ - 12), developed and validated by Luthans, Youssef at al. (2007). It was provided by Mind Garden (www.mindgarden.com) already translated into Portuguese, and revised by bilingual professionals. The PCQ - 12 measures four dimensions of the construct (self-efficacy, optimism, hope and resilience) and had already been translated into Portuguese by the authors themselves.

The PCQ - 12, was validated for Portugal by Viseu, Jesus, Reus, Ng and Cara-Linda (2012). These authors confirmed the validity of PQC- 12 as a good measure of the four dimensions of the construct. Other authors such as Avey, Luthans and Mhatre, (2008), stated that the PCQ - 12 ensured the validity of the construct and its suitability for longitudinal studies.

Employees were asked to answer the questionnaire on a Likert Scale, between 1 "I totally disagree" and 6 "I entirely agree" with each sentence in the questionnaire. Examples of statements in the questionnaire are: "I feel confident representing my area of work in management meetings"; "I can only count on myself in the job if needed"; "I am optimistic about what is going to happen in my job in the future".

Using LISREL (version 8.8), we conducted a confirmatory factor analysis of these scales, starting with the author's model (M1), then the one-dimensional model (M2) and the secondorder factor model (M3).

The results obtained by both models showed that the $M 1$ had a better goodness of fit (X2: 84.63; RMSEA: 0.050; GFI: 0.92; X2 / df: 1.76; AIC Model: 144.63) and its values complied with Hair et al. (2010). We therefore decided to use it. Even taking into account that the optimism dimension only consists of two items, which goes against Hair et al. (2010), who tells us that the minimum acceptable number of items per factor should be four, this final factorial solution (M2) it tallies with the theoretic framework proposed by Luthans, Youssef et al. (2007). We therefore decided to use model M2.

\section{Results}

We now show the descriptive statistics of the latent variables that are part of this study (Table 1). The values shown in the table are weighted taking into account the factor loading of the items in each variable of the models resulting from a confirmatory analysis (models with best goodness of fit index). 


\begin{tabular}{|c|c|c|c|c|c|c|c|c|c|c|c|c|c|}
\hline & & $\mathbf{M}$ & DP & 1 & 2 & 3 & 4 & 5 & 6 & 7 & 8 & 9 & 10 \\
\hline $\begin{array}{l}\text { 1. Authentic } \\
\text { Leadership } \\
\text { (Global) }\end{array}$ & $(04)$ & 1,75 & 0,676 & $(0,942)^{*}$ & & & & & & & & & \\
\hline $\begin{array}{l}\text { 2. Relational } \\
\text { transparency } \\
\text { (A.L.) }\end{array}$ & $(0-4)$ & 1,68 & 0,659 & $0,312 * *$ & $(0,824) *$ & & & & & & & & \\
\hline $\begin{array}{l}\text { 3. Internalized } \\
\text { moral } \\
\text { perspective } \\
\text { (A.L.) }\end{array}$ & $(0-4)$ & 1,89 & 0,794 & $0,274 * *$ & $0,783 * *$ & $(0,851)^{*}$ & & & & & & & \\
\hline $\begin{array}{l}\text { 4. Balanced } \\
\text { processing of } \\
\text { information } \\
\text { (A.L.) }\end{array}$ & $(0-4)$ & 1,68 & 0,793 & $0,273 * *$ & $0,748 * *$ & $0,753 * *$ & $(0,787) *$ & & & & & & \\
\hline $\begin{array}{l}\text { 5. Self- } \\
\text { awareness } \\
\text { (A.L.) }\end{array}$ & $(0-4)$ & 1,76 & 0,798 & $0,182 * *$ & $0,721 * *$ & $0,713 * *$ & $0,762 * *$ & $(0,864) *$ & & & & & \\
\hline 6. C.O. & $(1-7)$ & 3,56 & 1,312 & $0,202 * *$ & $0,256 * *$ & $0,321 * *$ & $0,278 * *$ & $0,281 * *$ & $(0,864) *$ & & & & \\
\hline $\begin{array}{l}\text { 7. Self-efficacy } \\
\text { (PyCap) }\end{array}$ & $(1-6)$ & 3,91 & 0,902 & $0,910 * *$ & $0,216 * *$ & $0,262 * *$ & $0,312 * *$ & $0,215^{* *}$ & $0,393 * *$ & $(0,834) *$ & & & \\
\hline $\begin{array}{l}\text { 8. Hope } \\
\text { (PsyCap) }\end{array}$ & $(1-6)$ & 3,12 & 0,639 & $0,906 * *$ & $0,237 * *$ & $0,260 * *$ & $0,258 * *$ & $0,236 * *$ & $0,442 * *$ & $0,547 * *$ & $(0,746) *$ & & \\
\hline $\begin{array}{l}\text { 9. Resilience } \\
\text { (PsyCap) }\end{array}$ & $(1-6)$ & 2,76 & 0,559 & $0,891 * *$ & $0,149 * *$ & $0,171 * *$ & $0,157 * *$ & $0,176 * *$ & $0,190 * *$ & $0,398 * *$ & $\mathrm{D}, 43 \mathrm{D}^{* *}$ & $(0,487)^{*}$ & \\
\hline $\begin{array}{l}\text { 10. Optimism } \\
\text { (PsyCap) }\end{array}$ & $(1-6)$ & 3,47 & 0,916 & $0,889 * *$ & $0,139 * *$ & $0,203 * *$ & $0,174 * *$ & $0,217 * *$ & $0,352 * *$ & $0,335 * *$ & $0,382 * *$ & $0,360 * *$ & $(0,717) *$ \\
\hline
\end{tabular}

* Cronbach Alphas. ** Correlation is significant at the 0.01 level ( 2 extremities)

Table 1. Means, standard deviations and correlations

Given the range of the scale used $(0-4)$ to measure authentic leadership, we find that the average value obtained by authentic leadership as a global construct and by its four dimensions, is slightly below the midpoint of the range, which is 2.5 . It is also showed that the results pointed to moderate positive correlations between dimensions, which is consistent with the theoretical framework proposed by several authors, e.g. Walumbwa et al. (2008).

In the case of commitment, the average obtained is slightly higher than the midpoint of the response scale (1-7), which is 3.5 .

The average obtained from analyzing dimensions comprising psychological capital took into account the scale (1-6) used, except that we were able to measure size resilience, which had a slightly lower average. All other dimensions had positive psychological capital above the midpoint of the scale, and we also found that all the variables were positively correlated with each other, moderately, which was consistent with the theoretical framework.

In conclusion, we found that all the correlations between variables were positive, with the most significant between the dimensions of positive psychological capital. This ties in with the theory of Luthans, Youssef et al. (2007), i.e. that the four dimensions of positive psychological capital interact with each other. 


\subsection{Testing the Hypotheses and Research Model}

Although the results justified a one-dimensional approach to authentic leadership, we decided to keep the four dimensions provided by the authors (Walumbwa et al., 2008).

The proposed model converged and introduced acceptable indicators of goodness of fit (Figure 2). However, we found that the structural relationships between the latent variables corresponded to the real dimensions of the lead (although high) and the variables corresponding to positive psychological capital and organizational commitment had less than 1.96 t-values, and were not statistically significant.

Taking into account that the relationship between variables is between -1 and 1 , there are values that are not acceptable, for example, the estimated value of balanced information processing dimension ( $A L$ ) and self-efficacy (PsyCap), which is 1.94 (t-value of 1.68). It is therefore not statistically acceptable, as it calls into question the proposed model in its authentic leadership component.

We found the estimated value of the relationship between authentic leadership and the dimension resilience (PsyCap) was not statistically significant, so we decided to run a new model without this relationship. These results suggest a strong influence of multicollinearity, as previously mentioned, so we decided to test a model in which authentic leadership appears as a unidimensional latent construct. This new model shows acceptable goodness of fit.

An analysis of standard estimates of existing equations allowed us to study the assumptions made, which was done using a methodology of structural equation modeling using LISREL (version 8.8). According to Gefen, Straub and Boudreau (2000), this allows you to answer a series of interrelated issues simply, systematically and comprehensively, i.e. it enables us to model the relationships between multiple independent and dependent constructs.

We found that authentic leadership exerts influence on the organizational commitment ( $\mathrm{H} 1$ not rejected) relationship but this is not very significant. As for the influence of authentic leadership on the four dimensions of positive psychological capital, we found that there was a significant relationship on the self-efficacy dimension hope ( $\mathrm{H} 2 \mathrm{a}$ not rejected) and the hope dimension ( $\mathrm{H} 2 \mathrm{~b}$ not rejected) is negligible on the optimism scale ( $\mathrm{H} 2 \mathrm{~d}$ not rejected). The hypothesis assuming that authentic leadership influences resilience $(\mathrm{H} 2 \mathrm{c})$ was rejected because the values were not statistically significant in the statistical analysis.

Finally, as to the influence that each of the dimensions of psychological capital has on the profile of impairment, none of the proposed hypotheses ( $\mathrm{H} 3 \mathrm{a}, \mathrm{H} 3 \mathrm{~b}, \mathrm{H} 3 \mathrm{C}$ and $\mathrm{H} 3 \mathrm{D}$ ), were rejected. However, the hypothesis assumed that the influence of resilience on organizational commitment $(\mathrm{H} 3 \mathrm{C})$ shows a negative standardized estimate $(-0.23)$ and the value of $t$-values is negligible. 


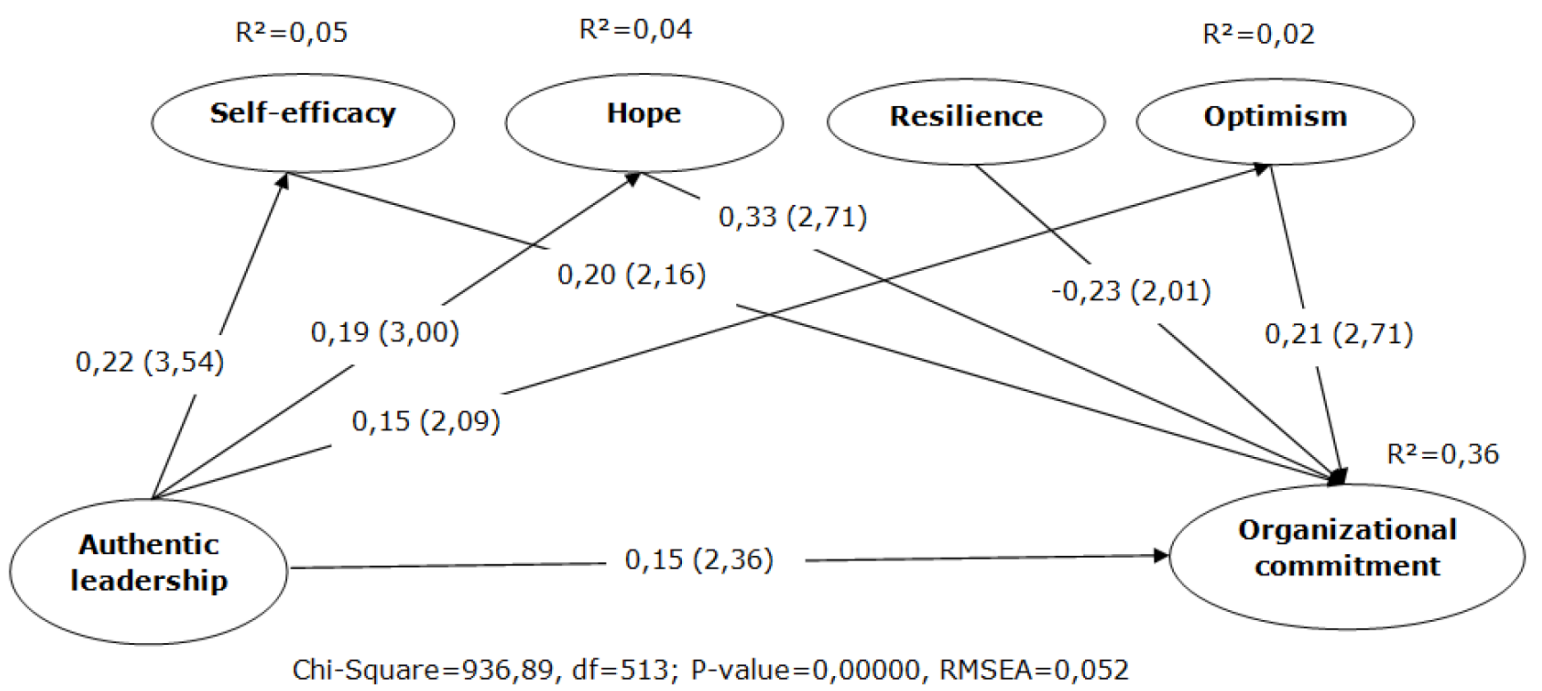

Figure 2. Results of the final model

Looking at the diagram of the overall final model, we can infer that, given that authentic leadership arises in the study as a predictor of positive psychological capital (mediator variable), the dimension that achieved the highest $R^{2}$ was self-efficacy with $R^{2}=0.05$. As for authentic leadership as a predictor of organizational commitment (dependent variable), 36\% $\left(R^{2}=0.36\right)$ of the total variance can be explained by authentic leadership.

Turning to the chances of mediation, we agree with several authors suggest that the way in which authentic leaders relate and interact with their followers leads to higher organizational commitment by individuals, as it generates higher levels of positive psychological capital. In other words, the development of Psycap produces higher levels of commitment (Walumbwa et al., 2008; Ilies et al., 2005; Rego et al., 2012; Gardner et al., 2005; Avolio et al., 2004; Norman et al., 2005; Luthans, Avolio, Avey \& Norman, 2007; Luthans et al., 2008; Avey et al., 2011).

Baron and Kenny (1986) asserted that "To test for mediation, one should estimate the three following regression equations: first, regressing the mediator on the independent variable; second, regressing the dependent variable on the independent variable; and third, regressing the dependent variable on both the independent variable and on the mediator" (Baron \& Kenny, 1986: page 1177).

In addition, the same authors also state that to test the hypotheses of mediation some assumptions must be met, and three conditions must exist to confirm the effect of mediation: a) the independent variable significantly affects the mediator variable and the dependent variable; b) the mediating variable significantly affects the dependent variable; $c$ ) the mediator varies significantly and affects the relationship between the independent variable and the dependent variable. 
As such, and according to these authors' assumptions, we propose in the present study to test an indirect effect of mediation. We chose to use the criteria of MacKinnon, Lockwood, Hoffman, West and Sheets (2002).

Indirect mediation was tested through the $z$ ', which is one of many models that the authors refer to in their study. The z' value for a significance level of 0.05 seconds MacKinnon et al. (2002) has a critical value of 0.97.

Thus, for the mediation of authentic leadership / self-efficacy / organizational commitment, there was a $z^{\prime}$ value of 1.57 , which is significant. The same applies to mediation of authentic leadership / hope / organizational commitment in which the $z^{\prime}$ value is 1.69 , and authentic leadership in mediation / optimism / organization whose commitment $z^{\prime}$ value is 1.52 .

\section{Discussion}

We sought to answer the initial question proposed for this research and test our hypotheses with a statistical analysis of data obtained using the techniques mentioned above. The results support H1, which is consistent with Walumbwa et al. (2008), i.e. authentic leadership has influence on organizational commitment. Taking account of the results obtained by the confirmatory analysis of organizational commitment that suggest a profile of $A C$ / dominant NC, commitment, we can say that authentic leadership also influences the normative dimension.

The results point to non-rejection of $\mathrm{H} 2$, i.e. that authentic leadership positively influences the PsyCap of followers, which is consistent with the theoretical framework proposed by several authors, who reported that the attitudes and behaviours of an authentic leader stimulated the PsyCap of his/her followers (Gardner et al., 2005; Avolio et al., 2004; Ilies et al., 2005; Norman et al., 2005).

The results point to non-rejection of the hypotheses that authentic leadership positively influences self-efficacy ( $\mathrm{H} 2 \mathrm{a})$, authentic leadership positively influences hope $(\mathrm{H} 2 \mathrm{~b})$ and authentic leadership positively influences optimism $(\mathrm{H} 2 \mathrm{~d})$. These results confirm what is suggested by several authors, which is that an authentic leader's behaviour influences and stimulates different PsyCaps in his/her followers (Avolio et al., 2004; Yammarino et al., 2008; Ilies et al., 2005; Norman et al., 2005).

However, the results suggest the rejection of the hypothesis that authentic leadership positively influences resilience $(\mathrm{H} 2 \mathrm{c})$, which goes against some authors, who reported that authentic leadership influenced resilience, and consequently positively influenced performance and organizational commitment (Avolio et al., 2004; Norman et al., 2005; Walumbwa et al., 2008; Luthans et al., 2005; Luthans, Youssef \& Avolio, 2006). However, in part, this result is 
justified as suggested by several authors. In view of the results obtained, we have doubts about the actual nature of resiliency, i.e. it is a more personal construct than the other dimensions of positive psychological capital and is therefore not determined by variables external to the individual (Luthans \& Youssef, 2004), such as leadership authentic.

The results confirm H3, i.e. that positive psychological capital positively influences organizational commitment, going back to some authors, who reported in their studies that positive psychological capital positively affects organizational performance and commitment (Luthans, Avolio et al., 2007; Luthans et al., 2008; Avey et al., 2011).

Finally, the results point to non-rejection of the hypotheses; self-efficacy positively influences commitment ( $\mathrm{H} 3 \mathrm{a})$; hope positively influences commitment $(\mathrm{H} 3 \mathrm{~b})$; resilience positively influences commitment $(\mathrm{H} 3 \mathrm{c})$ and optimism positively influences commitment $(\mathrm{H} 3 \mathrm{~d})$. This confirms several authors' theories that consider that all dimensions of positive psychological capital are positively correlated with organizational commitment (Avey et al., 2011; Luthans et al., 2005; Luthans et al., 2006). The influence for resilience was negative, however. In short, the final results obtained confirm that positive psychological capital mediates the relationship between authentic leadership and organizational commitment.

\section{Conclusions}

The final results suggest the one-dimensionality of the authentic leadership construct, to the extent that strong correlations were obtained between the four dimensions and high values in the relations of determining the dimensions. This leads to the use of the authentic leader construct as one-dimensional imaging, due to the multicollinearity phenomenon.

One of the most interesting results suggests that resilience can negatively affect (?) organizational commitment (Hypothesis H3). The greater an individual's resilience, the lower their organizational commitment to the organization is, particularly in its moral dimension, i.e. affective and normative moral profile as established by Meyer and Parfyonova (2010). Organizational studies that include resilience are recent. Although it has long been known in psychology it has only recently been measured as meeting the POB criteria (Luthans, 2002; Luthans \& Youssef, 2004; Lopes \& Cunha, 2005). This construct is defined as "positive psychological capacity to respond to adversity, uncertainty, conflict, failure and even positive change, progress and increased responsibility" (Luthans, 2002: page 702).

In the same vein, several authors consider that as resilience is not a specific and not solely likely to be enhanced at organizational level, given its importance to the objectives and organizational strategy and the current organizational context, organizations should implement strategies for developing it because this characteristic could translate into a competitive 
advantage (Luthans \& Youssef, 2004). However, the same authors argue that failure of these strategies can lead to unwanted and harmful outcomes for both parties.

Luthans and Youssef (2004) even suggest that resilience is a long journey throughout life as part of people's development process, taking into account the context and the environment, and that it is a process and not a goal. Considering our results, we wonder about the actual nature of resilience. That is it is a more personal construct, unlike the other dimensions of positive psychological capital, and therefore cannot be determined by variables external to the individual, such as authentic leadership. Rather than undermining an established framework, these results may be a factor in the development of new studies, aligning the perspective of Popper (2003) of a need for refutation of situations (a particular established theoretical framework) to progress this same theoretical framework.

We question the positioning of resilience and its influence on organizational commitment, comparing it with other constructs of a negative nature, such as organizational cynicism (Assis \& Nascimento, 2014) or a positive determination between normative organizational commitment and negligence found by Nascimento (2010).

Finally, our results show that positive psychological capital is an important variable in the relationship between authentic leadership and organizational commitment. They confirm the importance and reinforce the need for organizations to implement strategies to develop it.

\subsection{Limitations and Future Studies}

A major limitation was the fact that the survey used to collect the data from the three variables simultaneously was lengthy, so it may have resulted in less reliable answers, which certainly had an impact on the data obtained.

A second limitation has to do with the current organizational and social context experienced by individuals. Current constraints can lead to people being conditioned in the organization and looking at their leaders with suspicion. This reality may have affected the way the respondents answered and their willingness to answer the questionnaire.

A third limitation lies in the knowledge that one has of oneself, as this may have influenced the answers to the questionnaire, especially when it came to positive psychological capital, because the instrument used as a reference for obtaining data on this construct (PCQ - 12) compelled individuals to analyze and know themselves.

As the final results show, authentic leadership does not have anything to do with resilience, and the results indicate that this dimension of positive psychological capital negatively influences organizational commitment. 
Given these results and the fact that all theoretical evidences indicate precisely the opposite, we recommend a longitudinal study (as it ensures more reliable data), involving the dimensions of the three variables under study here, but in similar cultural and socio-economic contexts, and comparing the results with those obtained in this study, in order to assess whether there is any other variable that may explain these results.

Finally, taking Luthans, Youssef et al. (2007) into account when they say that we should invest in PsyCap as a whole, we suggest a study of the impact of authentic leadership in which its followers could be measured, for example, in terms of productivity, well-being and citizenship in two separate teams, where one only invested in some of the dimensions of PsyCap and on the other in all the dimensions. This could prove not only the theories of authors such as Luthans, Youssef et al. (2007), but also prove what Gardner et al. (2005) and Walumbwa et al. (2008) reported in their studies, i.e. that both variables are important in an organizational context.

\section{Acknowledgement}

This work was supported by Portuguese national funds through FCT - Fundação para a Ciência e a Tecnologia, under project «Pest-OE/CJP/UI0713/2013».

\section{References}

Allen, N.J., \& Meyer, J.P. (1990). The measurement and antecedents of affective, continuance, and normative commitment to the organization. Journal of Occupational Psychology, 63, 1-18. http://dx.doi.org/10.1111/j.2044-8325.1990.tb00506.x

Avey, J.B., Luthans, F., \& Mhatre, K.H., (2008), A call for longitudinal research in positive organizational behavior. Journal of Organizational Behavior, 29(5), 705-711. http://dx.doi.org/10.1002/job.517

Avey, J.B., Reichard, R.J., Luthans, F., \& Mhatre, K.H. (2011). Meta-analysis of the impact of positive psychological capital on employee attitudes, behaviors, and performance. Human Resource Development Quarterly, 22, 127-152. http://dx.doi.org/10.1002/hrdq.20070

Avolio, B.J., Gardner, W.L., Walumbwa, F.O., Luthans, F., \& May, D.R. (2004). Unlocking the mask: A look at the process by which authentic leaders impact follower attitudes and behaviors. The Leadership Quarterly, 15, 801-823. http://dx.doi.org/10.1016/j.leaqua.2004.09.003 
Assis, D.J.P.F.M.S., \& Nascimento, J.L.R.P. (2014). O papel do comprometimento profissional na relação entre o cinismo e o comprometimento organizacional: um modelo conceptual. XXIV Jornadas Luso Espanholas de Gestão Cientifica. 6, 7, 8 Fevereiro, Leiria

Baron, R.M., \& Kenny, D.A. (1986). The moderator-mediator variable distinction in social psychological research: Conceptual, and statistical considerations. Journal of Personality and Social Psychology, 51(6), 1173-1182. http://dx.doi.org/10.1037/0022-3514.51.6.1173

Becker, H. (1960). Notes on the concept of commitment. American Journal of Sociology, 66, 32-42. http://dx.doi.org/10.1086/222820

Gardner, T.W.L., Avolio, B.J., Luthans, F., May, D.R., \& Walumbwa, F. (2005). Can you see the real me? A self-based model of authentic leader and follower development. The Leadership Quarterly, 16, 343-372. http://dx.doi.org/10.1016/j.leaqua.2005.03.003

Gefen, D., Straub, D.W., \& Boudreau, M.C. (2000) Structural equation modeling and regression: Guidelines for research practice. Commun AIS, 4, 1-77.

Harter, J.K., Schmidt, F.L., \& Hayes, T.L. (2002). Business-unit level relationship between employee satisfaction, employee engagement, and business outcomes: A metaanalysis. Journal of Applied Psychology, 87(2), 268-279. http://dx.doi.org/10.1037/0021-9010.87.2.268

Harter, S. (2002). Authenticity. In Snyder, C.R. \& Lopez, S. (Eds.). Handbook of positive psychology (pp. 382-394). Oxford, UK: Oxford University Press.

Hair, J., Black, W., Babin, B., \& Anderson, R. (2010). Multivariate data analysis: A global perspective. 7a ed. New Jersey: Pearson Prentice Hall.

Ilies, R., Morgeson, F.P., \& Nahrgang, J.D. (2005). Authentic leadership and eudaemonic well-being: Understanding leader-follower outcomes. The Leadership Quarterly, 16, 373-394. http://dx.doi.org/10.1016/j.leaqua.2005.03.002

Kernis, M.H. (2003). Toward a Conceptualization of Optimal Self-Esteem. Psychological Inquiry, 14, 1-26. http://dx.doi.org/10.1207/S15327965PLI1401_01

Kernis, M.H., \& Goldman, B.M., (2005). From thought and experience to behavior and interpersonal relationships: A multicomponent conceptualization of authenticity. In Tesser, A., Wood, J.V., \& Stapel, D. (Eds.). On building, defending and regulating the self (pp. 31-52). New York: A psychological perspective.

Lopes, M.P. (2013). A Dialectical Approach to Positive Organizational Studies. American Journal of Industrial and Business Management, 3, 185-195. http://dx.doi.org/10.4236/ajibm.2013.32024 
Lopes, M.P., \& Cunha, M.P. (2005). Mindpower: O Valor do Capital Psicológico Positivo. RH Magazine, 41, 30-41.

Luthans, F., (2002). The need for meaning of positive organizational behavior. Journal of Organizational Behavior, 23, 695-706. http://dx.doi.org/10.1002/job.165

Luthans, F., \& Avolio, B. (2003). Authentic leadership: a positive development approach. In Cameron, K.S., Dutton, J.E., \& Quinn, R.E. (Eds.). Positive Organizational Scholarship. San Francisco, CA: Berrett-Koehler. 241-258.

Luthans, F., \& Youssef, C.M. (2004). Human, Social, and Now Positive Psychological Capital Management: Investing in People for Competitive Advantage. Organizational Dynamics, 33(2), 1-36. http://dx.doi.org/10.1016/j.orgdyn.2004.01.003

Luthans, F., Avey, J.B., Clapp-Smith, R., \& Li, W. (2008). More evidence on the value of chinese workers' psychological capital: A potentially unlimited competitive resource? The International Journal of Human Resource Management, 19, 818-827. http://dx.doi.org/10.1080/09585190801991194

Luthans, F., Avolio, B., Avey, J.B., \& Norman, S.M. (2007). Psychological capital: Measurement and relationship with performance and satisfaction. Personal Psychology, 541-572.

Luthans, F., Avolio, B., Walumbwa, F., \& Li, W. (2005). The Psychological Capital of Chinese Workers: Exploring the relationship with performance. Management and Organization Review, 1(2), 249-271. http://dx.doi.org/10.1111/j.1740-8784.2005.00011.x

Luthans, F., Luthans, K.W., \& Luthans, B.C. (2004). Positive psychological capital: Beyond human and social capital. Business Horizons, 47(1), 45-50.

http://dx.doi.org/10.1016/j.bushor.2003.11.007

Luthans, F., Youssef, C.M., \& Avolio, B.J. (2006). Psychological capital: Investing and developing positive organizational behaviour. In Cooper, C.L., \& Nelson, D. (Eds.). Positive organizational behaviour: Accentuating the positive at work. Thousand Oaks, C.A. http://dx.doi.org/10.1093/acprof:oso/9780195187526.001.0001

Luthans, F., Youssef, C.M., \& Avolio, B.J. (2007). Psychological Capital: Developing the human competitive edge. Oxford, UK: Oxford University Press.

MacKinnon, D.P., Lockwood, C.M., Hoffman, J.M., West, S.G., \& Sheets, V. (2002). A comparison of methods to test mediation and other intervening variable effects. Psychological Methods, 7(1), 83-104. http://dx.doi.org/10.1037/1082-989x.7.1.83 
Mathieu, J.E., \& Zajac, D.M. (1990). A Review and Meta-Analysis of the Antecedents, Correlates, and Consequences of Organizational Commitment. Psychological Bulletin 1990, 108(2), 171-194. http://dx.doi.org/10.1037/0033-2909.108.2.171

Meyer, J.P., \& Allen, N.J. (1997). Commitment in the work place. Thousand Oaks, CA: Sage Publications.

Meyer, J.P., \& Allen, N.J. (1991). A Three component conceptualization of organizational commitment. Human Resource Management Review, 1(1). http://dx.doi.org/10.1016/10534822(91)90011-Z

Mayer, J.P., \& Herscovitch, L. (2001). Commitment in the workplace Toward a general model. Human Resource Management Review, 11, 299-326. http://dx.doi.org/10.1016/S1053-4822(00)00053$x$

Meyer, J.P., \& Parfyonova, N.M. (2010). Normative commitment in the workplace: A theoretical analysis and re-conceptualization. Human Resource Management Review, 20(4), 283-294. http://dx.doi.org/10.1016/j.hrmr.2009.09.001

Meyer, J.P., Allen, N.J., \& Topolnytsky, L. (1998a). Commitment in a changing world of work. Canadian Psychology/Psychologie canadienne, 39(1-2), 83-93. http://dx.doi.org/10.1037/h0086797

Meyer, J.P., Irving, G.P., \& Allen, N.J. (1998b). Examination of the combined effects of work values and early work experiences on organizational commitment. Journal of Organizational Behavior, 19, 29-52. http://dx.doi.org/10.1002/(SICI)1099-1379(199801)19:1<29::AID-JOB818>3.0.CO;2-U

Meyer, J.P., Stanley, D.J., Herscovitch, L., \& Topolnytsky, L. (2002). Affective, continuance, and normative commitment to organization: A meta-analysis of antecedents, correlates, and consequences. Journal of Vocational Behavior, 61(1), 20-52.

http://dx.doi.org/10.1006/jvbe.2001.1842

Nascimento, J., (2010). Influência do comprometimento organizacional nas estratégias comportamentais, mediada pelo comprometimento com os objectivos e pela satisfação global com o trabalho. Doctoral thesis in management. ISCSTE -IUL.

Nascimento, J., Lopes, A., \& Salgueiro, M.F. (2008). Estudo sobre a validação do "Modelo de Comportamento Organizacional" de Meyer e Allen para o contexto português. Comportamento Organizacional e Gestão, 4(1), 115-133.

Ng., T.W., \& Feldman, D.C. (2008). Can you get a better deal elsewhere? The effects of psychological contract replicability on organizational commitment over time. Journal of Vocational Behavior, 73, 268-277. http://dx.doi.org/10.1016/j.jvb.2008.05.004 
Norman, S., Luthans, B., \& Luthans, K. (2005). The proposed contagion effect of hopeful leaders on the resiliency of employees and organizations. Journal of Leadership and Organizational Studies, 12(2), 55-64. http://dx.doi.org/10.1177/107179190501200205

Popper, K., (2003). Conjunturas e refutações. Editora Almedina.

Rego, A., Sousa, F., Marques, C., \& Cunha, M.P. (2012). Authentic leadership promoting employees psychological capital and creativity. Journal of Business Research, 65, 429-437. http://dx.doi.org/10.1016/j.jbusres.2011.10.003

Seligman, M.E. (2005). Positive Psychology, Positive Prevention, and Positive Therapy. In Lopez, S.J., \& Snyder, C.R. (Eds.). Handbook of positive psychology. Oxford University Press.

Viseu, J., Jesus, S.N., Reus, C., Nunes, H., \& Cara-Linda, I., (2012). Capital Psicológico e sua avaliação com o PCQ-12. ECOS - Estudos Contemporâneos da Subjectividade, 2(1), 4-16.

Walumbwa, F., Avolio, B., Gardner, W., Wernsing, T., \& Peterson, S. (2008). Authentic Leadership: Development and Validation of a Theory-Based Measure. Journal of Management, 34(1), 89-126. http://dx.doi.org/10.1177/0149206307308913

Yammarino, F.J., Dionne, S.D., Schriesheim, C.A., \& Dansereau, F. (2008). Authentic leadership and positive organizational behaviour: A meso. Multi-level perspective. Leadership Quarterly, 19(6), 693-707. http://dx.doi.org/10.1016/j.leaqua.2008.09.004

Youssef, C.M., \& Luthans, F. (2007). Positive organizational behavior in the workplace: The impact of hope, optimism, and resilience. Journal of Management, 33(5), 774-778. http://dx.doi.org/10.1177/0149206307305562

Journal of Industrial Engineering and Management, 2016 (www.jiem.org)

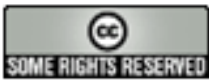

Article's contents are provided on an Attribution-Non Commercial 3.0 Creative commons license. Readers are allowed to copy, distribute and communicate article's contents, provided the author's and Journal of Industrial Engineering and Management's names are included. It must not be used for commercial purposes. To see the complete license contents, please visit http://creativecommons.org/licenses/by-nc/3.0/. 